\title{
Kelly Staples
}

Statelessness and the politics of misrecognition

Department of Politics and International Relations, University of Leicester, Leicester, United Kingdom

University Road, Leicester, LE1 7RH

Email: kls25@le.ac.uk

Tel.: +441162523003

Fax: +441162525082 


\begin{abstract}
This article focuses on the account of disrespect found in Honneth's theory of recognition. In it, I am particularly interested in the form of misrecognition or disrespect which is the negation of respect, and which is clearly represented by statelessness. Respect, for him, is closely connected to legal recognition. Guided by Honneth's view of critical theory as 'not entirely without a foundation in social reality' (Honneth 1994, p.264), the article puts together an analysis of the political dynamics of his model of disrespect. This analysis is used to challenge certain aspects of Honneth's political theory and in particular the implications of his conception of the state. The article argues that the way in which the state is used has the effect of obscuring significant political obstacles to recognition, and in particular, the way in which the state limits respect.
\end{abstract}

\title{
Keywords
}

Honneth; misrecognition; recognition; respect; statelessness

\section{Introduction}

This article focuses on the account of disrespect found in Honneth's theory of recognition. In it, I am particularly interested in the form of misrecognition or disrespect which is the negation of respect, and which is clearly represented by statelessness. Respect, for him, is closely connected to legal recognition. Guided by Honneth's view of critical theory as 'not entirely without a foundation in social reality' (Honneth 1994, p.264), the article puts together an analysis of the political dynamics of the chosen model of disrespect. This analysis is used to challenge certain aspects of Honneth's political theory and in particular the implications of his universalism. The article argues that this universalism has the effect of obscuring significant political obstacles to recognition, and in particular, the way in which the state limits respect.

In important works in international relations (e.g. Frost 1996) and political theory (e.g. Honneth 1996), the concept of recognition has been used to try to resolve the supposed tension between the universality of the human experience and the particularity of the social relations which mediate our experiences. Recognition theory has also made valuable contributions to the debate about rightsrespect. As we will see, the particular benefits of respect are such that it can stabilise the unpredictability (Arendt 1973, p.301) of other social relationships. Relationships of friendship and love are understood by recognition theorists and those interested specifically in statelessness to be characterised by uncertainty, in contrast to the certainty conferred by rights-respect. In its analytical form, recognition theory has helped theorise the way in which, in modern states, more idiosyncratic recognition of our 'particular traits and abilities' is supported and strengthened by the universality of respect (Zurn 2000, p.116). 
This article is motivated by my interest in the moral experiences of disrespect (Honneth 1994, p.268) of stateless persons. Of course, it has long been argued that the stateless are themselves representative of the tension between the universal abstraction of human rights and the particularity which characterises the system of sovereign states (Arendt 1973). This tension is illustrated by the United Nations charter system. While the Universal Declaration of Human Rights outlines the universal right to a nationality, and to 'recognition as a person everywhere before the law' (United Nations 1948), it holds at the same time that it is 'the sovereign right and responsibility of each State to determine, through the operation of its law, who are its citizens' (UNHCR 2004, VIII/2). Inevitable protection gaps (Batchelor 1995) arise because access to the ostensibly universal right to recognition is mediated by sovereign states with extensive discretionary jurisdiction. Those persons whom no state recognises as nationals go on to lack recognition everywhere due to the importance of 'legal personality' (United Nations 1949, p.17) to individual status. At the time of writing, there are estimated to be twelve million stateless persons (UNHCR 2011) outside of the normal relationships which constitute citizenship in its most basic sense.

Hannah Arendt despaired of the prospects of bringing stateless persons back into the intersubjective domain of politics. In her account of disrespect, rightlessness was equivalent to 'expulsion from humanity' (Arendt 1973, p.297). In what follows, I will first show how Honneth's 'pre-theoretical' ontology of disrespect (Honneth 1994, p.268) might help mitigate the pessimism of Arendt's account, outlining a space for meaningful intersubjectivity unmediated by the state. In the end, however, the article finds that Honneth's reliance on the state leads him to reproduce a conception of its essential character, and to overlook the potentially harmful results of the state's particular relationships of recognition. The article as a whole also attempts to demonstrate that Honneth's attempt to 'decenter' the idea of autonomy (Honneth 2007b, p.183) lacks sufficient critical appreciation of the damaging effects of the state, and of the particularity which remains central to the enjoyment of respect. In this way, the relational promise of Honneth's theory is diluted. While the normative theory of recognition can articulate the individual person's need for recognition, it cannot - for as long as it rests on assumptions about the normative coherence (Cochran 1999, p.109) of the state - fully account for the practical difficulties of attaining it.

\section{I}

Honneth is justifiably well-known for his work on recognition. His work attempts to demonstrate the importance of the social relations of communication which are the causes of the 'systematic violation of the conditions of recognition' (Honneth 1994, p.264). According to this model, the task of critical theory is to put together a critique of societal relations that 'is not entirely without a foundation in social reality' (Honneth 1994, p.268). The aspiration to a degree of epistemological certainty rests on 
an external ontology of disrespect. For Honneth, the moral experience of disrespect constitutes 'a pretheoretical resource' (Honneth 1994, p.268) which can be used in constructing critical accounts of particular social relations. Honneth's broad theory of misrecognition, or disrespect, builds on the Hegelian distinction between three patterns of recognition necessary for the 'successful development of identity' (Honneth 1994, p.263). As I will show here, there are various theoretical advantages associated with this differentiated ontology of recognition. Among these is the way that it becomes possible to understand respect as desirable, rather than necessary, for personhood. I aim to show that this sense of respect as conditional and non-necessary helps us to reconsider the "the right to have rights'. This understanding of rights-respect has often been understood as paradoxical insofar as it suggests that rights - the very bases of personhood - are contingent on a discretionary right controlled by states.

It is worth spending a few moments outlining the relationship between respect and rights in Honneth's theory. As Thompson notes, 'Honneth's account of recognition [...] draws a tight connection between respect and rights' (Thompson 2006, p.44). A 'politics of respect' as outlined by recognition theory therefore, 'is a way of thinking about and acting in the political world which gives a prominent place to [...] themes of equal protection, difference-blindness, state impartiality and individual freedom' (Thompson 2006, p.44). In Honneth's theory, 'rights are the only means' by which respect can be expressed (Thompson 2006, p.59). Indeed, 'legal recognition' is used in his work as 'a synonym for respect' (Ibid.). Honneth's account fits, therefore, with Arendt's account of rightlessness (1966), in which inclusion in a political community is shown to be the sole effective guarantor of access to equal protection. It is well-known that Arendt was extremely pessimistic about the universal promise of juridical rights tied into a nation-state framework (Arendt 1973, p.275). However, I want here to offer some initial grounds for a constructive approach to conceiving of the potential for the development of a constructive theory of personhood. Theories of recognition have, in important ways, served as a critical counter to atomistic accounts of subjectivity. I hope to show that recognition theory also offers scope for overcoming Arendtian pessimism about the equivalence of disrespect and 'expulsion from humanity' (1973, p.297). Here and throughout I will use 'disrespect' to mean the lack of rightsrespect often said to characterise statelessness. Therefore, while English translations of Honneth's work use 'disrespect' to refer both to misrecognition generally, and to the lack of love, esteem, and respect, the focus here is on the absence or denial of rights-respect.

Arendt was understandably pessimistic about the prospects for resolution of statelessness. She argued persuasively that the division of the world into sovereign states meant that with the loss of political status, the stateless 'no longer belong to any community whatsoever': 'Their plight is not that they are not equal before the law, but that no law exists for them' (Arendt 1973, p.296). With the complete organization of humanity (Arendt 1973, p.297), the state becomes the arbiter of the ostensible 
universality of 'the right of man'. State membership is therefore a prerequisite of 'the right to have rights'. It is in this sense that 'the loss of home and political status become[s] identical with expulsion from humanity altogether' (Arendt 1973, p.297). In Arendt's view there is no pre-political subject. For her, citizenship represents a necessary political status and a legally constituted personality, without which we are left:

[...] with those qualities which usually can become articulate only in the spheres of private life and must remain unqualified [...]. This mere existence [...] can be adequately dealt with only by the unpredictable hazards of friendship and sympathy, or by the great and incalculable grace of love (Arendt 1973, p.301).

Arendt had real concerns about the 'dark background of mere givenness' (Arendt 1973, p.301) inevitable to the condition of rightlessness. Her account of the 'peculiar state of nature' that the rightless are forced to inhabit describes a situation of 'unqualified, mere existence' (Arendt 1973, p.301-2). Certainly, she seems right to point to the way in which political rights are constitutive of a special status. Practically speaking, being a citizen implies a status of being qualified, as, say, French or British. ${ }^{1}$ For Honneth, it facilitates autonomy because it permits self-respect, allowing 'a person to understand herself as someone who possesses the capacities - the prerequisites of competent subjectivity and agency - that make her appear as a full member of society' (van den Brink and Owen 2007, p.13). In his view, while legal status is not, strictly-speaking, necessary for effective personhood, legal recognition is constitutive of a specific form of status. While we can thus, on Honneth's account, live without the specific forms of recognition which qualify us as 'full members', doing so will require us to live a greatly restricted life.

While her work has been very influential, many have found Arendt's theory unsatisfying due to its inescapable conclusion that the stateless person is less than human. Jacques Rancière has described this position as an 'ontological trap' (Rancière 2004, p.302) produced by her 'rigid opposition between the realm of the political and the realm of private life' (Rancière 2004, p.299). His suggestion for escaping this unnecessary trap is to reconceive the ontology of the so-called rights of man. For Rancière, the fact that these rights are written down and inscribed in political institutions gives them indicative content, the specifics of which can be determined politically. 'Man' and 'citizen' are in his view 'political predicates, open to dispute and contestation' (Rancière 2004, p.303). He finds it problematic to accept the kind of inside/outside framework which has often been used to exclude

\footnotetext{
${ }^{1}$ The criteria for qualification vary within and between states. In most states, qualification is based on either place of birth or parent's nationality. Most states also reserve the right to naturalise non-citizens, in which case, qualification often implies a literal test.
} 
social groups from political rights. In his view, Arendt's private/political opposition gives unnecessary power to the idea that the line between life and political life can ever be clearly drawn (Rancière 2004, p.303). While I leave aside the detail of his argument here, I want to take forward the idea that there is potentially something productive in the move away from a dualistic ontology of private/public; of exclusion/inclusion.

There is similar potential in Honneth's pre-theoretical ontology of disrespect. I think Honneth would agree with Arendt's assertion that '[w]e are not born equal; we become equal as members of a group on the strength of our decision to guarantee ourselves mutually equal rights' (Arendt 1973, p.301). His own Hegelian theory differs from Arendt, however, in his clear assertion that rights are not necessary, in the strong sense, to individual personhood. He holds instead that the rights derived from 'reciprocal relations of recognition' are necessary for 'full human flourishing' (Anderson 1996, p.xxi). Honneth is also relatively optimistic about the realm of the personal, which is shown to be a source of recognition (love) and misrecognition (lack of love), though not of respect. Indeed, he claims that the most fundamental sort of personal degradation 'is the lack of basic self-confidence that results from an absence of love' (Honneth 1996, p.132). This account of subjectivity has the benefit of emphasising the extent to which the grievous harms we suffer are often due to the action or omission of other, known, subjects, rather than to the violation of our abstract rights. It is an account which is also able to account for the fact that - against considerable odds - many people denied respect have derived a strong sense of self from family and from other social networks (Bloch and Schuster 2005, p.493; Malkki 2002, p.359; Nyers 2004, p.214). The fact that respect 'represents a historically variable quantity' (Honneth 1996, p.134), which can be measured 'in terms of the degree of universalization' (Ibid.), does not therefore mean that disrespect completely undermines the self.

Respect is, for Honneth, ostensibly a non-appraisive, formalised model of reciprocity. The reciprocal arrangements which mediate respect imply equality in a way that the arrangements of love and social esteem do not. For this reason, respect has a stabilising function. Respect places limits on the outcomes and effects of familial and social misrecognition, affording individuals some degree of guaranteed equality. There is, in Honneth, a general assumption that the covenant between citizens and states generates formal protections, as well as our necessary acknowledgement of the equal rights of our fellow-citizens. Thus, while he has much to say about the importance of respect, it is not held to be fundamental, in the strong sense, to personhood. This suggests that we may be able to loosen the paradoxical hold of 'the right to have rights' on the theory of personhood.

II

There seem to be valid theoretical reasons to take steps to avoid the 'ontological trap' that equates recognition with personhood in the strong sense by setting up an unnecessary opposition between the 
private and the political. We have seen so far that the pre-theoretical experience of disrespect helps Honneth avoid the self-defeating conclusion that relations of respect are necessary pre-requisites of personhood. Even though he retains a clear distinction between the private and the political, his Hegelian understanding of recognition enables him to avoid conceiving of personhood as a zero-sum property. However, I want to suggest that the normative dimension of his theory recreates the constraints of that trap insofar as it leads Honneth towards an insufficiently critical appreciation of respect.

For Honneth, self-respect is a universalising form of social recognition. The violation of respect is therefore particularly devastating; it 'typically brings with it a loss of [...] the ability to relate to oneself as a legally equal interaction partner with all fellow humans' (Honneth 1996, p.134). By implication, then, respect serves a universalising function which is in turn normatively grounded in the Kantian intuition that 'the claims of all subjects to equal respect for their individual autonomy enjoy absolute priority' over other recognition claims (Honneth 2007, p.141). In his view, respect is distinct from love and esteem insofar as it has emerged historically with the development of a morality that is expressed in the idea of human rights (van den Brink and Owen 2007, p.12). Respect is therefore characteristic of the type of 'recognition-respect' which 'denotes a normative nonappraisive attitude towards an individual qua personhood' (Owen 2007, p.304). It refers to a type of recognition which does not make reference to an individual's particular abilities and traits (Ibid.). As both Arendt and Honneth see it, legal recognition confers a status which is public in character (Honneth 1996, p.120), and is neutral towards our private, personal qualities and traits. Respect is constitutive not only of the ability to participate in a given community. For him, it is constitutive of the ability to participate "with equal rights, in the institutional order as a full-fledged member of a community' (Honneth 1996 p.133).

Analytically speaking, this interpretation makes sense. It conforms with the legal reality that citizenship is the pre-requisite of a wide range of rights, as well as being equivalent to legal personality. However, it is one thing to make the analytical point that the state has universalising effects, and quite another to make the normative point that the universal demands of self-respect justify the state. In the first point, the universal value is contingent on the state. As we have seen, one of the implications of this standpoint is that personhood is made dependent on given political relations. The second position appears to circumvent this strong contingency by asserting a prior account of universal subjectivity. However, in doing so, it de-historicises personhood, making it impossible to think critically or coherently about the social causes of the 'systematic violation of the conditions of recognition' (Honneth 1994, p.264). Both types of theory are therefore prone to being caught in an 'ontological trap' resulting from a too-strong public/private opposition. However, Honneth's account offers a third alternative. His theory retains the intersubjectivity which makes 
appreciation of social misrecognition possible, combining it with a plurality which acknowledges that it is possible to retain attributes of personality even when one is excluded from the political relations which are constitutive of self-respect.

While Arendt found (and I would argue, correctly) that the complete organisation of humanity rendered the concept of 'man' too weak to anchor personhood, we have seen that the dualist private/political ontology on which her theory rests again puts a theory of personhood beyond our reach. More promisingly, Honneth's theory allowed for intersubjectivity in a way that reoriented personhood away from a zero-sum conception. He furthermore tries to ground the possibility of full personhood in the potential of practical autonomous judgements about just and unjust social and political relations. The demands of autonomous judgement are said by Honneth to require arrangements which will facilitate 'the equal ability of all to lead a human life' (Honneth 2007c, pp.208-9). And he is optimistic that our capacity for decision-making makes the greater achievement of full human flourishing possible (Honneth 2007c, p.208). To the extent that the state is judged to be a practical condition of human flourishing it will be understood as a rational political arrangement. However, Honneth's strong intersubjectivism when it comes to personhood should prevent him from resorting to essentialist claims about its value. Nevertheless, there seems to be a slippage in Honneth's account towards the claim that the state is - after all - a necessary condition of personhood. In what follows, I will try to show how this slippage occurs.

While the plurality of Honneth's pre-theoretical ontology of disrespect opened up potential avenues for the achievement of recognition, his eventual reliance on the state damages the early promise in avoiding the Arendtian problem. In a recent essay in which he talks about universal rights, Honneth states that:

Since all these rights are intersubjective in character, they apply to all other human beings and this entails individual duties, but in most cases the fulfilment of these duties is possible only when they are transferred to the jointly constituted institution of the state (Honneth 2007c, p.209).

This strong claim takes Honneth down a path which is overly-optimistic about the state's function as the solution for disrespect in general and statelessness in particular. This is problematic for at least three reasons. First, justifying political arrangements by reference to the state may undermine a further aspect of Honneth's theory, namely his use of the Kantian idea of the possibility of 'autonomous' judgement. It is arguable that the arbitrary authority of the state renders it incompatible with the kind of autonomous judgement Kant had in mind. I will deal with this objection first. A second problem with Honneth's theoretical use of the state is that it risks reintroducing a zero-sum, 'in or out' model of recognition. The final objection relates to the way in which this in/out conception 
becomes so problematic. Therefore in the final section of this article, I outline the discriminatory sources and cumulative exclusions of state misrecognition.

Honneth has been one of the foremost theorists of misrecognition. However, his work has also been subject to various criticisms. Lois McNay's major criticism of his theory holds that it ignores the power relations which are often (if not always) structural conditions of respect, and hence of legal rights. She calls on Honneth (and other recognition theorists) to embed their insights in a 'sociological understanding of power relations' (McNay 2007, p.3), and to avoid theories in which 'the idea of recognition is naturalized and universalized' (McNay 2007, p.3). Her critique of recognition focuses on the ways in which recognition and misrecognition are contingent on power. She makes substantial use in this critique of Bourdieu's concept of 'symbolic power' (Bourdieu 1990). Bourdieu's critique of the state argues that existing power can become 'symbolic' and hence 'endowed with a specific symbolic efficacy' when its 'arbitrary truth' is 'recognized as legitimate' (Bourdieu 1990, p.112). Weber's argument that the state is the holder of the monopoly of legitimate violence is upheld as emblematic of the construction of symbolic power. McNay's argument is that Honneth risks granting symbolic power to an arbitrary political relationship, and hence to the outcomes of its political processes.

As a way of avoiding these problems, McNay advocates sticking with an analytical, rather than normative, approach to recognition. She suggests that recognition theory often relies on an 'unexamined conflation of the normative and analytical functions of the idea of recognition with the effect that the former limits the critical purchase of the latter' (McNay 2007, p.8). Thus she argues that:

In order to render recognition plausible as an ideal of self-realization and equality, sociological barriers to its possible implementation must necessarily be diminished or construed as contingent, secondary effects of power. Thus problematic aspects to the reproduction of subjectivity that pertain to the pervasive and insidious nature of social domination are underplayed. This is achieved through the disconnection of an understanding of an analysis of power relations, with the consequence that the idea of recognition fails to grasp some important dimensions to the reproduction of social inequalities (McNay 2007, p.8).

McNay's argument here is helpful for thinking about Honneth's use of the state. Honneth's theory is both analytical and normative. The normative part of his work rests on a strand of Kantian universalism in his theory of recognition, which argues that the concept of autonomy - 'which since Kant has become self-evident' (Honneth 2007b, p.185) - restricts the range of justifiable social relationships. Insofar as this applies to respect, it identifies as unjust acts such as legal discrimination 
against whole social groups (Honneth 2007, p.136) which 'harm or even destroy the self-respect we acquire in seeing the value of our judgement recognized by other persons (Honneth 2007, p.136).

$\mathrm{He}$ is interested in constructing an autonomous (in the Kantian sense of non-arbitrary) justification of respect as an ideal of self-realisation. While conscious of the contingency of full human flourishing and the plurality of relations of recognition, he remains interested in providing a justification of personhood from which we can derive normative limits on permissible social and political relations. He clearly wants to steer a path between the nihilism of an all-or-nothing account of political intersubjectivity (what we might call the Arendtian problem) and the asocial, apolitical character of some accounts of individual agency. He chooses to make use of Kantian intuitions about autonomy in charting this course. His use of Kant recalls O'Neill's claim that Kantian autonomy can serve as a basis for non-conditional justifications for action (O’Neill 2003). This type of Kantianism represents a particular way of making practical judgements in the face of apparent contradictions (Honneth 2007, p.141). Autonomy on this understanding is neither a contingent nor foundational attribute of persons, but is rather an attribute of reasoned judgements which are reached independently of existing - and therefore arbitrary - authorities (O’Neill 2003, pp.9-10). In Honneth's own words, autonomy represents the property of "judgments to which we can ascribe the predicate "moral" (Honneth 2007b, p.184). It is therefore a concept which reasserts the possibility of external judgement in circumstances of complex intersubjectivity. In practice, it implies that '[b]ecause we have to recognize all human beings as persons who enjoy equal rights to autonomy, we may not choose social relationships whose realization would require a violation of those rights' (Honneth 2007, p.141). Kantian autonomy of this kind gives normative 'expression to the moral or legal rights to which all responsible persons ought to be entitled' (Honneth 2007b, p.185).

An important feature of Honneth's argument about the concept of autonomy is that it is essentially indeterminate (Honneth 1996, p.110). By this he means that there is no a priori set of social and political conditions for its realisation. This 'structural openness' is therefore said to facilitate 'a gradual increase in inclusiveness and provision' (Honneth 1996, p.110) in that it sets out the normative possibility of full human flourishing in the absence of either a pre-political conception of the person or a fully contingent conception of personhood. However, he has also claimed that this ideal is to be fulfilled by the 'jointly constituted institution of the state' (Honneth 2007c, p.209). I have started to suggest that his understanding of the state as an intersubjectively constituted institution might obscure the extent to which it is constituted by structural power. A specific problem with this kind of understanding of the state is that it neglects the extent to which the state retains exclusive jurisdiction over the types of political recognition necessary for the achievement of self-respect. The symbolic power he grants the state risks legitimising its particularity, and is in any case inconsistent with his aspiration to autonomous judgement. 


\section{III}

I have tried to show how Honneth's reliance on the state both undermines the early promise of this theory in circumventing the ontological trap which has so often constrained the theory of personhood. I have also tried to show that, from an immanent perspective, it undermines his Kantian aspirations. The last point that I want to make refers to the long history of state misrecognition and legal discrimination, and the cumulative effects which are exacerbated by theories which grant symbolic power to the state. Notwithstanding the development of international human rights law, there is widespread consensus that the stateless person's lack of 'recognized identity' (UNHCR 2010) severely compromises the autonomy of the individual, especially in respect of political rights and the right to residence (UNHCR 2009, p.39). The continuing absence of alternative sources of legal rights in these and other areas makes statelessness problematic. I also want to show that Honneth's understanding of the objective, non-appraisive character of legal rights is problematic for his theory of disrespect.

The misrecognition of stateless persons is perhaps the clearest evidence of the arbitrary and exclusionary power of the state. In practice, statelessness has dual effects. It both strips the individual of the political status of citizenship, and strips her of her status 'in the international political community' (US Supreme Court 1958). The cumulative deprivations of statelessness should make us sceptical of theories which make normative connections between the state and the idealised 'ability to relate to oneself as a legally equal interaction partner with all fellow humans' (Honneth 1996, p.134). While Honneth's theory of misrecognition is alert to the fact that violation of the conditions of respect generally entails the loss of this ability (Ibid.), he has less to say about the manner in which we can reconcile a commitment to full personhood with a commitment to the state. Indeed, for as long as we remain wedded to a conception of the state as the source of legal rights, we seem destined to remain caught in the ontological trap which grants states full power over self-respect.

Thompson is among those critics who have made important points about the relationship between power and legal rights. He writes about the fairly common situation where a social group finds itself 'deprived of rights which others enjoy because another group has wielded its greater political power or has utilized its greater resources in order to achieve this result' (Thompson 2006, p.61). The practical and symbolic power of the state legitimises the outcomes of political struggles for recognition which are in some cases highly appraisive, if not invidious. This criticism of the state system can be applied to Honneth's theory to the extent that he is led to legitimise the state in a way that facilitates exclusion and returns his intersubjective theory to a zero-sum conception of recognition. 
An interesting consequence of the kind of critical analysis of state power suggested by McNay and Thompson is the way in which it illustrates the deep social and political roots of legal rights. The need to appreciate the political and social mechanisms by which legal rights are constituted and constrained has long been recognised by theorists of statelessness. In many cases of statelessness, a person or group retains the documentary evidence of his or her former nationality. In point of fact, however, post hoc political decisions have stripped away the content of that status. This trend demonstrates an important truth: that while legal rights such as the right to a nationality or the right to recognition everywhere before the law seek to abstract personhood from its political and social roots, their grounding in political relationships is vital to their character. By locating these relationships within the sphere of the state and by characterising rights respect as non-appraisive, Honneth tends to obscure the fact that strictly legal understandings of rights, even where they are grounded in an intersubjective theory of personhood, can obscure the deeply discriminatory and appraisive forces which constitute and constrain the exercise of such rights. A couple of examples are helpful as illustrations here.

When rights were withdrawn from the German Jews in the 1930s, the Committee on International Assistance to Refugees concluded that "the fact that most of them still possess national passports is of no importance in view of the precarious nature of the documents in their possession and the fact that, as a rule, it is impossible for them to get their passports extended' (Kuhn 1936, p.497). In order to claim the legal rights to which citizenship would normally entitle Germans, the denationalised Jews would have to throw themselves on the mercy of a regime which judged them to be less than human. One of the first experts on statelessness therefore expressed deep concern that a strictly formal conception of citizenship which ignored its political dimensions would result in 'legal fiction' (Weis 1979, p.241). Clearly, state citizenship implies a continuing relationship of recognition, rather than being the objective embodiment of an abstract condition of full personhood. In many situations of statelessness today, the refusal of the state to acknowledge its relationship with some subset of de jure nationals renders those persons stateless.

A more recent example provides further evidence of the importance of the on-going political recognition which provides substance to the formalities of legal status. In 2007, UNHCR sought active co-operation with the government of Burma in respect of the status of its stateless Rohingya residents. As a result, thirty-five thousand Temporary Registration Certificates were issued by the authorities in Burma's Northern Arakan State. This was described at the time as 'a major first step towards legalizing the status of the Rohingyas' (Sam 2007). In fact, the documentation of this group tended to exacerbate their experiences of disrespect. In 2010, the government prevented the Rohingya from marrying, moving between villages, and repairing mosques without express permission (Living 
in a No-man's Land 2010). The continuing ability of the state to withdraw recognition of individuals and groups suggests that there is an insidious dimension to state powers of recognition (McNay 2007, p.8).

Rainer Forst has made some interesting points about the qualitative difference between a respect concept and a permission concept of toleration which are also relevant here (Forst 2007, p.219). His account of edicts of religious toleration demonstrates clearly the risks of a legal position which fixes one's position in 'a situation of being "merely" tolerated' (Forst 2007, p.218). Forst argues that permissive toleration, even when made juridical, often leads to 'cultural and social stigmatization, political powerlessness, and dependency' (Forst 2007, 218). The 'repressive and disciplinary effects' of such practices (Forst 2007, p.220) are serious obstacles to the achievement of the ideal of respect within the state. He argues that social struggles for recognition (including respect) will be difficult to achieve without some source of equality separate to the state. To the extent that legal recognition can have disciplinary effects, there is good reason to be wary of essentialising the state as the appropriate arrangement for Honneth's normative ideal of human flourishing.

In trying to make sense of the clear political dimensions of citizenship rights, it is helpful to revisit the distinction Honneth draws between esteem and respect. Misrecognition understood as lack of esteem refers to the kind of systematic denigration which makes self-esteem difficult to maintain (Ibid.). Esteem is the "the result of social and cultural struggles that lack the universality that is distinctive of legal relations' (Anderson 1996, p.xvii). In practice, however, it is very unclear that legal relations are universal in the manner Honneth imagines, rather than being - often if not always - contingent on local values. It is therefore unclear that the distinction between esteem and respect that Honneth wants to make is as clear-cut as he suggests.

For Honneth to move too quickly towards theoretical generalisation about the value of the state clearly risks underestimating the political limits and qualifications on recognition which run counter to his aspiration to autonomous justification. There remain significant obstacles to the achievement of personhood, and to the possibility of constructing an independent justification of respect while remaining committed to the state. Honneth's normative claim that we may not choose social relationships whose realisation would require a violation of persons' equal rights to autonomy (Honneth 2007, p.141) seems rather incompatible - in the light of his commitment to the state - with the reality that legal rights are often contingent on local patterns of esteem. One response would be to opt, as McNay suggests, for an analytical, rather than normative account of recognition, which might facilitate a more critical engagement with its present scope and limits. However, it may be possible to retain the aspiration to a normative theory of recognition by letting go of the normative conception of the state. By introducing the state into his attempt to articulate a normative justification of recognition, 
Honneth undoes his good work in sidestepping the Arendtian problem of a zero-sum conception of recognition. For states, as we know, retain exclusive but concurrent competence in respect of political recognition (Weis 1979, p.165). Recognition, when performed by the state is most definitely not nonappraisive; it is predicated on particular political arrangements and entails the possibility of repression. As Lynch notes, 'statelessness and disputed nationality can only be addressed by the very governments that regularly breach protection and citizenship norms' (Lynch 2005, p.1). Such cases demonstrate the depressing dependence of respect in all cases on state power, and in many cases, on the highly appraisive social relations of esteem within given states. Political and legal discrimination is often premised on collective traits such as ethnicity, religion or gender, rather than strictly individual qualities. More broadly, the ostensibly objective law which underpins legal personality is premised on the adjudication of difference and, in extreme cases, damaging violations of the principle of equality. In several countries, political status represents merely the juridical guarantee of "the symbolic capital that [agents] have acquired in previous struggles' (Bourdieu 1990, p.135).

\section{Conclusion}

There remain important advantages to constructing an account of personhood which construes recognition as practically valuable, though not absolutely essential, to basic personhood. However, it has been shown to be risky to underestimate the obstacles to recognition in general, and respect in particular. This article has attempted to highlight the basis of state recognition in exclusive power arrangements. In practice, these arrangements often mean that 'respect' is the mere outcome of appraisive, and even discriminatory social practices. For as long as the normative ideal of respect is predicated on a normative conception of the state, the ostensibly autonomous rights Honneth seeks to articulate will be difficult to grasp. State-based rights do not represent 'the depersonalized symbols of social respect' (Honneth 1995, p.119). In many parts of the world, political recognition is highly personalised. In the state system as a whole, political recognition is contingent on deeply particularist structures of power. By introducing a normative conception of the state into his theory, Honneth risks a slide back into the problem faced by the stateless, and reconstructed by Arendt, in which the state is the gatekeeper of full personhood.

\section{Acknowledgements}

This article was presented in an earlier form at The Politics of Misrecognition conference at the University of Bristol in January 2010, co-organised by Simon Thompson, Wendy Martineau and Nasar Meer. I am very grateful to the organisers, and to all those who participated in the conference. I am also grateful to colleagues at the University of Leicester, to whom an earlier version of this work was also presented in 2010. 


\section{References}

Anderson, Joel. 1996. Translator's Introduction. In The Struggle for Recognition: The Moral Grammar of Social Conflicts, Axel Honneth, x-xxi. Cambridge MA: The MIT Press.

Arendt, Hannah. 1973. Origins of Totalitarianism $5^{\text {th }}$ edition. San Diego: Harcourt, Brace, Jovanovich.

Batchelor, Carol. 1995. Stateless Persons: Some Gaps in International Protection. International Journal of Refugee Law 7: 232-259.

Bloch, Alice, and Liza Schuster. 2005. At the extremes of exclusion: Deportation, detention and dispersal. Ethnic and Racial Studies 28: 491-512.

Bourdieu, Pierre. 1990. In Other Words: Essays Towards a Reflexive Sociology. Cambridge: Polity.

Cochran, Molly. 1999. Normative Theory in International Relations: A Pragmatic Approach. Cambridge: Cambridge University Press.

Forst, Rainer. 2007. "To Tolerate Means to Insult" Toleration, Recognition, and Emancipation. In Recognition and Power: Axel Honneth and the Tradition of Critical Social Theory, ed. Bert van den Brink and David Owen, 215-37. Cambridge: Cambridge University Press.

Frost, Mervyn. 1996. Ethics in International Relations: A Constitutive Theory. Cambridge: Cambridge University Press.

Honneth, Axel. 2007. Between Aristotle and Kant: Recognition and Moral Obligation. In Disrespect: The Normative Foundations of Critical Theory, 129-143. Cambridge: Polity

Honneth, Axel. 2007b. Decentred Autonomy: The Subject After the Fall. In Disrespect: The Normative Foundations of Critical Theory, 181-194. Cambridge: Polity

Honneth, Axel. 2007c. Is Universalism a Moral Trap? In Disrespect: The Normative Foundations of Critical Theory, 197-217. Cambridge: Polity

Honneth, Axel. 1996. The Struggle for Recognition: The Moral Grammar of Social Conflicts. Cambridge MA: The MIT Press.

Honneth, Axel. 1994. The Social Dynamics of Disrespect: on the location of critical theory today. Constellations 1: 255-269.

Kuhn, Arthur. 1936. International Measures for the Relief of Stateless Persons. The American Journal of International Law 30: 495-99.

2010. Living in a No-man's Land. The Irrawaddy, 14 January, http://www.irrawaddy.org/article.php?art_id=17499. Accessed 22 December 2010.

Lynch, Maureen. 2005. Lives on Hold: The Human Cost of Statelessness. Washington DC: Refugees International.

Malkki, L. 2002. News from Nowhere: Mass Displacement and Globalized "Problems of Organization”. Ethnography 3: 351-60.

McNay, Lois. 2007. Against Recognition. Cambridge: Polity.

Nyers, Peter. 2004. 'Introduction: What's Left of Citizenship?' Citizenship Studies 8: 203-15. 
O'Neill, Onora. 2003. Autonomy: The Emperor's New Clothes. The Aristotelian Society: Supplementary Volume 77: 1-21.

Owen, David. 2007. Self-Government and 'Democracy as Reflexive Co-operation': Reflections on Honneth's Social and Political Ideal. In Recognition and Power: Axel Honneth and the Tradition of Critical Social Theory, ed. Bert van den Brink and David Owen, 290-320. Cambridge: Cambridge University Press.

Price, Richard M. 2008. Moral Limits and Possibility in World Politics. Cambridge: Cambridge University Press.

Rancière, Jacques. 2004. Who is the Subject of the Rights of Man? South Atlantic Quarterly 103: 297310.

Sam, Khun. 2007. Burma Agrees on Identity Cards for Rohingyas. The Irrawaddy 24 July, http://www.irrawaddy.org/article.php?art_id=7983. Accessed 22 December 2010.

Thompson, Simon. 2006. The Political Theory of Recognition: A Critical Introduction. Cambridge: Polity.

UNHCR. 2011. Stateless People: Searching for Citizenship, http://www.unhcr.org/pages/49c3646c155.html. Accessed 22 March 2011.

UNHCR. 2010. Faster state accessions needed for statelessness conventions. Monthly Updates http://www.unhcr.org.uk/resources/monthly-updates/october-2010/statelessness.html. Accessed 11 March 2011.

UNHCR. 2009. Addressing Situations of Statelessness. Geneva: UNHCR.

UNHCR. 2004. Resettlement Handbook. Geneva: UNHCR.

United Nations. 1949. A Study of Statelessness. New York: UN.

United Nations. 1948. Universal Declaration of Human Rights. New York: UN.

United States Supreme Court. 1958. Judgement of the Court: Trop v. Dulles, http://www.law.cornell.edu/supct/html/historics/USSC_CR_0356_0086_ZO.html. Accessed 22 December 2010.

van den Brink, Bert and David Owen. 2007. Introduction. In Recognition and Power: Axel Honneth and the Tradition of Critical Social Theory, ed. Bert van den Brink and David Owen, 1-32. Cambridge: Cambridge University Press.

Weis, Paul. 1979. Nationality and Statelessness in International Law. Andover: Steven and Sons. Zurn, Christopher. 2000. Review essay: Anthropology and normativity: a critique of Axel Honneth's 'formal conception of ethical life'. Philosophy and Social Criticism 26: 115-24. 